\title{
Creation and Expansion of a Virtual COVID-19 Information Exchange Platform Using the Brazilian University Telemedicine Network (RUTE)
}

\author{
Felipe A Fraga ${ }^{1}$, Evelyn Eisenstein ${ }^{2}$, Luiz A Messina ${ }^{3}$, Max P Moraes ${ }^{4}$, Cristiane Kopacek ${ }^{5}$, Denise de C M Zornoff ${ }^{6}$, \\ David Cirigussi ${ }^{7}$, Gustavo P Fraga ${ }^{8}$
}

\begin{abstract}
Introduction: Due to Brazil's alarming situation, Brazilian professionals decided to create a Special Interest Group about coronavirus disease2019 (SIG COVID-19 Brazil RUTE-the Brazilian University Telemedicine Network) with the objective of promoting training sessions by web conference for professional and medical students.

Aim and objective: To describe the experience of rapidly organizing this professional network based on telemedicine activity and share its initial results.

Materials and methods: The structure adopted was MConf, a web conference platform that provides a virtual conference channel for 75 active participants and online video streaming for an additional unlimited number of attendees. The agenda started with meetings occurring 3 times a week, which were changed to weekly encounters in July, and are scheduled to be monthly in August. The interactive presentations lasted 30-40 minutes, with approximately 20 minutes for written or spoken debate. After each presentation, all participants were invited to register their presence and answer brief evaluation questions about the quality of the presentation, with an evaluation score ranging from 1 (poor) to 10 (excellent).

Results: From March 23 to June 30, 2020, forty-one web conferences were presented in the areas of epidemiology, medicine (different specialties), nursing, physiotherapy, dentistry, and new technologies, with the participation of 52 speakers from 12 Brazilian states and 12 international guest speakers from 9 countries: Israel, Italy, United States of America, Spain, Switzerland, Portugal, Canada, Ecuador, and Qatar. The program had in its coverage 2,170 registrations by 857 participants from 135 distinct institutions. The conference's attendance average reached up to 100 participants. Around $60 \%$ of the attendees answered the program's quality survey; the average evaluation score for quality of transmission, professional contribution; and topic relevance were 9.0,9.5, and 10, respectively.

Conclusion: The experience of working with telemedicine was determinant to create the innovative SIG COVID-19 Brazil RUTE, providing an important learning experience on diagnosis, treatments, and outcomes for the COVID-19 crisis management.
\end{abstract}

Keywords: COVID-19, Distance learning, Medical education, Pandemy, Telemedicine, Web conferences.

\section{Resumo}

Introdução: Devido à situação alarmante causada pela chegada do COVID-19 no país, profissionais brasileiros ligados à Rede Universitária de Telemedicina (RUTE) decidiram criar um Grupo de Interesse Especial sobre o COVID-19 (SIG COVID-19 Brasil RUTE), para promover sessões de treinamento para profissionais da área da saúde e estudantes.

Objetivo: Apresentar a experiência de organizar rapidamente essa rede profissional, com base em uma atividade de Telemedicina, e compartilhar seus resultados iniciais.

Materiais e métodos: A estrutura adotada foi o MConf, uma plataforma de webconferência que permite 75 participações simultâneas e uma conexão adicional por streaming com número ilimitado de participantes. A agenda começou com reuniões três vezes por semana, que passaram ao regime semanal em julho e mensal em agosto. As apresentações interativas tiveram duração de 30 a 40 minutos, com aproximadamente 20 minutos para debate. Após cada apresentação, todos os participantes foram convidados a registrarem a presença e responderem a breves perguntas de avaliação sobre a qualidade da apresentação, com uma pontuação de avaliação variando de 1 (ruim) a 10 (excelente).

Resultados: De 23 de março a 30 de junho, foram realizadas 41 webconferências nas áreas de epidemiologia, medicina (diferentes especialidades), enfermagem, fisioterapia, odontologia e novas tecnologias, com a participação de 52 oradores de 12 estados brasileiros e 12 oradores internacionais de 9 países: Israel, Itália, Estados Unidos da América, Espanha, Suíça, Portugal, Canadá, Equador e Catar. Esse programa teve mais de 1.500 participantes, e a presença diária nas conferências atingiu 100 participantes, em média. Cerca de $60 \%$ dos participantes avaliaram a qualidade do programa e, a pontuação média de avaliação de qualidade de transmissão, contribuição profissional, relevância do tópico foram, respectivamente, 9,0, 9,5 e 10.

Conclusão: A experiência de trabalhar com Telemedicina foi determinante para criar o inovador SIG COVID-19 Brasil RUTE, fornecendo importante experiência de aprendizado em diagnóstico, tratamentos e resultados para o gerenciamento de crises do COVID-19.

Palavras-chave: COVID-19, Pandemia, Telemedicina, educação a distância, ensino médico, webconferencia.

Panamerican Journal of Trauma, Critical Care \& Emergency Surgery (2020): 10.5005/jp-journals-10030-1291

(c) The Author(s). 2020 Open Access This article is distributed under the terms of the Creative Commons Attribution 4.0 International License (https://creativecommons. org/licenses/by-nc/4.0/), which permits unrestricted use, distribution, and non-commercial reproduction in any medium, provided you give appropriate credit to the original author(s) and the source, provide a link to the Creative Commons license, and indicate if changes were made. The Creative Commons Public Domain Dedication waiver (http://creativecommons.org/publicdomain/zero/1.0/) applies to the data made available in this article, unless otherwise stated. 


\section{INTRODUCTION}

Throughout the beginning of 2020 , the scientific global community has been challenged by the new coronavirus disease-2019 (COVID-19) pandemic, characterized as a major threat to public health worldwide. It is a highly contagious disease, with clinical and major respiratory and systemic manifestations including dry cough, fever, and fatigue, and it has also been frequently associated with pulmonary involvement. ${ }^{1,2}$ In early February, the World Health Organization (WHO) published its first document regarding strategic preparedness and response to the COVID-19 outbreak, with the aim of guiding countries with overcrowded health systems. Nearly 40 days later, the disease was categorized by the $\mathrm{WHO}$ as a pandemic. ${ }^{3}$ The first case was confirmed in Brazil on February 21, 2020. ${ }^{4}$

Based on the daily data made available by the $\mathrm{WHO}$ as well as Brazilian regional diseases reports, it has been possible to track COVID-19 spread and lethality. ${ }^{5,6}$ The urgent need for training and building the capacity of multiple essential health professionals has been fundamental for changing public policies, since COVID-19 mortality reached 58,314 deaths on June $30 .^{7}$

Due to the country's alarming situation, allied to its social diversities and territorial extension, some professionals from different Brazilian states, most of them members of the Brazilian Telemedicine University Network (RUTE), ${ }^{8}$ created the Special Interest Group (SIG) about COVID-19 (SIG COVID-19 Brazil RUTE). ${ }^{9}$ The main objective of the SIGs is to promote training sessions by web conference, lectures, debates, protocol discussions, and research in various health areas and medical specialties for professionals and medical students at varied levels of experience.

The increasing development of technology has provided the ability to revolutionize different aspects of communication and reduce physical distances through real-time virtual interactions. These are the principles of telemedicine, whose objective is bringing together multiple universities and hospitals, with different pandemic assistance stages and procedures. ${ }^{10}$ It mainly provides an essential information exchange between professionals from Brazil and those from other countries.

The objectives of this study were to describe the experience of rapidly organizing a telemedicine-based professional network to share information regarding the COVID-19 pandemic through an RUTE's collaborative teleconference platform.

\section{Materials and Methods}

The RUTE Network was launched in 2006, and now it covers 139 telemedicine units in medical schools and teaching hospitals across all Brazilian states. The RUTE has 55 on-going Special Interest Groups (SIGs) that hold scientific video conference sessions, engaging 380 different health institutions. RUTE participating institutions are free to propose, create, and coordinate SIGs covering medical and health sciences topics, operating under RUTE's infrastructure. ${ }^{8,11}$ Any health institution or even basic units are able to participate in the SIGs sessions. On March 20th, 2020, the RUTE coordinator (LAM, from Vila Velha, ES) and three professors (GPF, from University of Campinas, SP; EE, from University of the State of Rio de Janeiro, RJ; and CK, from Federal University of Health Sciences of Porto Alegre, RS), who had never met before but had experience in participating in other SIGs in their specialties, joined a advisory conference with the mission of creating the denominated SIG COVID-19 Brazil RUTE. Other professionals, RUTE staff, and medical students were
${ }^{1}$ University of Taubaté (UNITAU), Taubate, São Paulo, Brazil

${ }^{2}$ University of the State of Rio de Janeiro (UERJ), Rio de Janeiro, Brazil

${ }^{3,4}$ RUTE, Brazilian Telemedicine University Network, Institutional Relations in Health, National Research and Education Network (RNP), Vila Velha, Espírito Santo, Brazil

${ }^{5}$ Federal University of Health Sciences of Porto Alegre (UFCSPA), Porto Alegre, Rio Grande do Sul, Brazil

${ }^{6}$ Pedagogical Support Nucleus, Botucatu Medical School-UNESP, Botucatu, São Paulo, Brazil

${ }^{7}$ School of Medical Sciences (SMS), University of Campinas (Unicamp), Campinas, São Paulo, Brazil

${ }^{8}$ Division of Trauma Surgery, School of Medical Sciences (SMS), University of Campinas (Unicamp), Campinas, São Paulo, Brazil

Corresponding Author: Gustavo P Fraga, Division of Trauma Surgery, School of Medical Sciences (SMS), University of Campinas (Unicamp), Campinas, São Paulo, Brazil, Phone: +55 19 3521-9450, e-mail: fragagp2008@gmail.com

How to cite this article: Fraga FA, Eisenstein E, Messina LA, et al. Creation and Expansion of a Virtual COVID-19 Information Exchange Platform Using the Brazilian University Telemedicine Network (RUTE). Panam J Trauma Crit Care Emerg Surg 2020;9(3):189-194.

Source of support: Nil

Conflict of interest: None

invited for the first online meeting to discuss the organization and planning of activities, and a WhatsApp ${ }^{\circledR}$ group (WhatsApp Inc.) with 16 members, from 10 different cities in Brazil, was created as an Organizing Committee to share information between members. ${ }^{12,13}$

The structure adopted was a web conference platform, MConf, initially developed under a working research group at National Research and Education Network (RNP) and now an RNP Service, which provides a virtual conference channel for 75 active participants and online video streaming for an additional unlimited number of attendees. ${ }^{14,15}$ The schedule was defined as 60 minutes meetings on every Monday, Wednesday, and Friday during lunchtime, with multidisciplinary topics. The conferences started on March 23rd, when the pandemic was at its beginning in Brazil. National and international speakers were invited to share their experience as well. These conferences changed to weekly occurrences in July, and the goal is keep once a week until the end of the pandemic. All web conferences are public, online, and with no costs for participation or presentation.

For each conference, an electronic flyer (Fig. 1) has been sent by e-mail to members of RUTE and via WhatsApp to different groups in the health area to facilitate rapid interest, with the support of some medical societies.

Each presentation occurred for 30-40 minutes, with approximately 20 minutes for questions and answers via spoken or written chat. All presentations were recorded and most of them, according to the presenters' authorization, are saved and available at http://wiki.rnp.br/display/RUTESIGCOVID19, allowing access by those interested in any topic at different times.

The Organizing Committee worked as a team to have a balance between the diverse interests and topics conforming to the evolution of the pandemic. After each presentation, all participants were invited to register their presence through a QR code, identify the city where live, and answer brief structured evaluation questions about the quality of transmission, professional contribution, and topic relevance. The answers were tabulated and analyzed with 
an evaluation score ranging from 1 (poor) to 10 (excellent), using Microsoft Excel ${ }^{\circledast}$. Only participants who answered the complete questionnaire were included.

The study obtained approval from RUTE Network review board.

\section{Results}

From March 23rd to June 30th, a total of 41 web conferences were presented in the areas of epidemiology, medicine (different

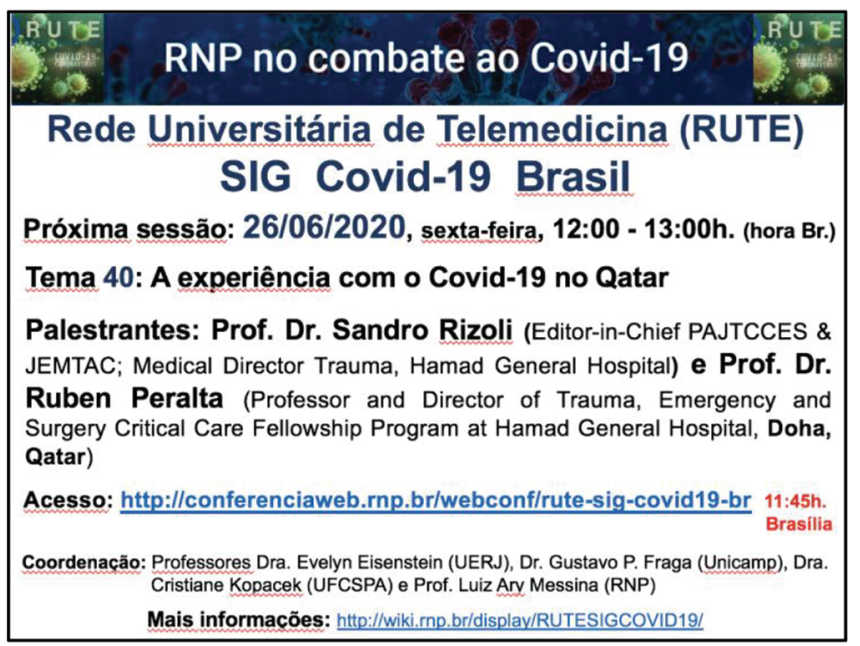

Fig. 1: Poster template for publicizing conferences specialties), nursing, physiotherapy, dentistry and new technologies, with the participation of 52 speakers from 12 Brazilian states and 12 international guest speakers from 9 countries: Israel, Italy, United States of America, Spain, Switzerland, Portugal, Canada, Ecuador, and Qatar. Table 1 shows the agenda with topics and speakers.

Therefore, with speakers from over a third of Brazilian states, the program had 2,170 registrations, by 857 participants from 135 distinct institutions. The conference's attendance at each session ranged from 48 to 150 participants, with a mean of 100, including streaming media. The attendee confirmation (Fig. 2) was filled for 857 participants who answered the questionnaire, which corresponded to approximately $60 \%$ of the audience at web conference platform during each session.

Based on the 802 complete answers received on the program's quality survey, the average evaluation score for quality of transmission, professional contribution, and topic relevance were $9.0,9.5$, and 10 , respectively.

The participants were from 52 cities, from every Brazilian state (26 in total) and the Federal District of Brasilia, as shown at Figure 3.

\section{Discussion}

The use of telemedicine has transformed the access and dissemination of information, especially when it comes to a global challenge to overcome a pandemic never seen in modern times. ${ }^{16,17}$ The possibility to connect different regions of the globe through teleconferences represents an opportunity to acknowledge the

Table 1: SIG COVID-19 Brazil RUTE agenda with topics covered until June and speakers

\begin{tabular}{|c|c|c|c|}
\hline Date & Topics & Speakers & City, state or country \\
\hline \multirow[t]{4}{*}{ March 23rd } & \multirow[t]{4}{*}{ Inaugural meeting of SIG COVID-19 Brasil RUTE } & Luiz Ary Messina & Vila Velha, ES, BR \\
\hline & & Gustavo P. Fraga & Campinas, SP, BR \\
\hline & & Evelyn Eisenstein & Rio de Janeiro, RJ, BR \\
\hline & & Cristiane Kopacek & Porto Alegre, RS, BR \\
\hline \multirow[t]{2}{*}{ March 25th } & \multirow{2}{*}{$\begin{array}{l}\text { Report on actions to combat COVID-19: Hospital Israelita Albert } \\
\text { Einstein and The Israel Center for Disaster Medicine and Humani- } \\
\text { tarian Response }\end{array}$} & Milton Steinman & São Paulo, SP, BR \\
\hline & & Elhanan Bar-On & Tel-Aviv, Israel \\
\hline \multirow[t]{2}{*}{ March 27th } & \multirow[t]{2}{*}{ Personal protection equipment } & Cristhieni Rodrigues & São Paulo, SP, BR \\
\hline & & Mariana Meszaros & Campinas, SP, BR \\
\hline March 30th & Covid-19: a great collective challenge-the Italian experience & Fabiane Barbosa & Milan, Italy \\
\hline April 1st & Clinical_-radiological correlation during COVID-19 pandemic & Rafael Grando & Porto Alegre, RS, BR \\
\hline April 3rd & Telemedicine outreach during the COVID-19 pandemic & Antonio Marttos Jr. & Miami, USA \\
\hline \multirow[t]{2}{*}{ April 6th } & \multirow{2}{*}{$\begin{array}{l}\text { COVID-19 emergency care in aid to the flow of patients at } \mathrm{HC} \text { - } \\
\text { Unicamp }\end{array}$} & Ricardo Affonso Ferreira & Campinas, SP, BR \\
\hline & & Gustavo P. Fraga & Campinas, SP, BR \\
\hline \multirow[t]{3}{*}{ April 8th } & \multirow[t]{3}{*}{ Appropriate COVID-19 testing for diagnoses } & Marilda Siqueira & Rio de Janeiro, RJ, BR \\
\hline & & Marilda de Lourdes & Rio de Janeiro, RJ, BR \\
\hline & & Oliveira & \\
\hline April 13th & Clinical aspects-COVID-19 & Albert Levy & New York, USA \\
\hline April 15th & COVID-19: impressions from Spain experience & Tiago Jeronimo & Madrid, Spain \\
\hline \multirow[t]{2}{*}{ April 17th } & \multirow[t]{2}{*}{ Evolution of the COVID-19 pandemic at Amazonas } & Bernardino Albuquerque & Manaus, AM, BR \\
\hline & & Pedro Elias & Manaus, AM, BR \\
\hline \multirow[t]{2}{*}{ April 22nd } & \multirow[t]{2}{*}{ Clinical aspects of COVID-19 in children and adolescents } & Luis Carlos Rey & Fortaleza, CE, BR \\
\hline & & Tiago Henrique Souza & Campinas, SP, BR \\
\hline April 24th & INCOR's experience in the TeleUTI COVID-19 network & Marco A. Gutierrez & São Paulo, SP, BR \\
\hline
\end{tabular}


Contd...

\begin{tabular}{|c|c|c|c|}
\hline Date & Topics & Speakers & City, state or country \\
\hline \multirow[t]{4}{*}{ April 27th } & \multirow[t]{4}{*}{ The challenges of oncology during COVID-19 times } & Alice Zelmanowicz & Porto Alegre, RS, BR \\
\hline & & Rafaela K. Dal Molin & Porto Alegre, RS, BR \\
\hline & & Stephanie Shahini & Porto Alegre, RS, BR \\
\hline & & Herb Riband & Geneva, Switzerland \\
\hline April 29th & Coagulopathy and thromboprophylaxis in COVID-19 & Erich de Paula & Campinas, SP, BR \\
\hline \multirow[t]{3}{*}{ April 30th } & \multirow{3}{*}{$\begin{array}{l}\text { Orienta + COVID-19: action of undergraduate students in the } \\
\text { health system }\end{array}$} & David Cirigussi & Campinas, SP, BR \\
\hline & & João Felipe & Campinas, SP, BR \\
\hline & & Fernanda Cristina & Campinas, SP, BR \\
\hline May 4th & $\begin{array}{l}\text { Diagnosis, monitoring and treatment in televideo consultation to } \\
\text { the patient affected with COVID-19 }\end{array}$ & Nando Campanella & Ancona, Italy \\
\hline May 6th & $\begin{array}{l}\text { Actions of the Pedro Ernesto University Hospital in facing the } \\
\text { pandemic of the new COVID-19 virus }\end{array}$ & Ronaldo Damião & Rio de Janeiro, RJ, BR \\
\hline May 8th & $\begin{array}{l}\text { Challenges of immunoglobulins and cytokines vs. viral epidemics/ } \\
\text { COVID-19 }\end{array}$ & Mario Geller & Rio de Janeiro, RJ, BR \\
\hline May 11 th & COVID-19 and pediatric endocrinology: what we need to know & Cresio Alves & Salvador, BA, BR \\
\hline May 13th & Updates on COVID-19 treatment & Otavio Berwanger & São Paulo, SP, BR \\
\hline \multirow[t]{2}{*}{ May 15th } & \multirow{2}{*}{$\begin{array}{l}\text { The experience of Hospital São Paulo and Hospital das Clínicas of } \\
\text { FMUSP with hospital dentistry in times of COVID-19 }\end{array}$} & Denise Abranches & São Paulo, SP, BR \\
\hline & & Juliana Franco & São Paulo, SP, BR \\
\hline \multirow[t]{2}{*}{ May 18th } & \multirow[t]{2}{*}{ Mechanical Ventilation of COVID-19 patient } & Jorge Luis Valiatti & Catanduva, SP, BR \\
\hline & & Antônio L. E. Falcão & Campinas, SP, BR \\
\hline May 20th & $\begin{array}{l}\text { Evolution curves of COVID-19 in Brazil and in the world: dispelling } \\
\text { some myths. }\end{array}$ & Mauro Pontes & Porto Alegre, RS, BR \\
\hline May 22nd & The panorama of health in recife in the face of COVID-19 & Jailson Correia & Recife, PE, BR \\
\hline May 25th & EBSERH's effort to mobilize and confront COVID-19 & Giuseppe C. Gatto & Brasília, DF, BR \\
\hline May 27th & Manaus Mission-Experience at the Epicenter of COVID-19 & Luciano S. Eifler & Porto Alegre, RS, BR \\
\hline \multirow[t]{2}{*}{ May 29th } & \multirow[t]{2}{*}{ Intubation in a patient with COVID-19 } & Guilherme Haelvoet & São Paulo, SP, BR \\
\hline & & Maurício Malito & São Paulo, SP, BR \\
\hline June 1st & Epidemiology of COVID-19 in Brazil_Epicovid 19 & Pedro Hallal & Pelotas, RS, BR \\
\hline \multirow[t]{2}{*}{ June 3 rd } & \multirow[t]{2}{*}{ Vulnerability indicators for COVID-19 in indigenous people } & Claudia Codeço & Rio de Janeiro, RJ, BR \\
\hline & & Marta Azevedo & Campinas, SP, BR \\
\hline \multirow[t]{5}{*}{ June 5th } & \multirow{5}{*}{$\begin{array}{l}\text { Challenges of neonatal screening in times of COVID19: experience } \\
\text { of RS and SP (SIG RUTE CONVID19-BR) }\end{array}$} & Giselle Yuri Hayashi & São Paulo, SP, BR \\
\hline & & Marcia Maria C. G. Giusti & São Paulo, SP, BR \\
\hline & & Simone M. de Castro & Porto Alegre, RS, BR \\
\hline & & Cristiane Kopacek & Porto Alegre, RS, BR \\
\hline & & Ana Maria Martins & São Paulo, SP, BR \\
\hline June 8th & Development of new vaccines and future prospects & Miriam Tendler & Rio de Janeiro, RJ, BR \\
\hline June 10th & Weaning and IMT (inspiratory muscle training) in the COVID-19 era & Lígia dos Santos Roceto & Campinas, SP, BR \\
\hline June 12th & Prophylaxis and early treatment of COVID-19 & Rosana Paiva & Sorocaba, SP, BR \\
\hline June 15th & $\begin{array}{l}\text { PrimaryCare@COVID-19 platform for the follow-up and monitoring } \\
\text { of chronic patients }\end{array}$ & Luís Lapão & Lisbon, Portugal \\
\hline June 17th & $\begin{array}{l}\text { The COVID-19 prevention at workplace-the role of occupational } \\
\text { medicine }\end{array}$ & Rose Copelman & Rio de Janeiro, RJ, BR \\
\hline \multirow[t]{3}{*}{ June 19th } & \multirow{3}{*}{$\begin{array}{l}\text { PHYDIGITAL, how physical and digital are connected in the new } \\
\text { normal }\end{array}$} & Raphael Souza & Toronto, Canada \\
\hline & & Lília Porto & Fortaleza, CE, BR \\
\hline & & Leonardo Aguiar & Blumenau, SC, BR \\
\hline June 22 nd & Care for pregnant women and babies during times of COVID-19 & Natasha SIhessarenko & Cuiabá, MT, BR \\
\hline June 24th & COVID-19-situation and management in Ecuador & Francisco Xavier S. Salazar & Quito, Ecuador \\
\hline \multirow[t]{2}{*}{ June 26th } & Experience with COVID-19 in Qatar & Sandro Rizoli & Doha, Qatar \\
\hline & & Ruben Peralta & Doha, Qatar \\
\hline June 29th & COVID-19 and genetics & Salmo Raskin & Curitiba, PR, BR \\
\hline
\end{tabular}




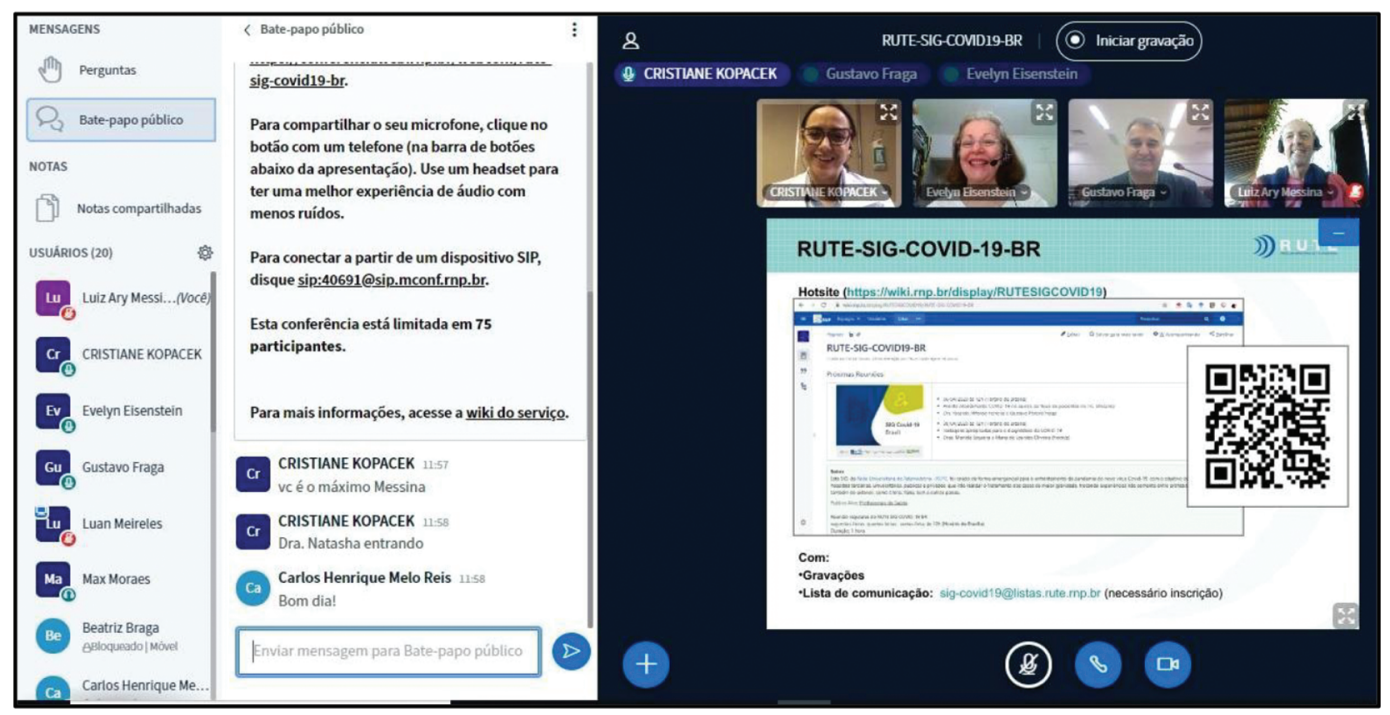

Fig. 2: QR code to register presence at the end of each session

distinguished procedures, methods, and stages of the disease evolution. $^{18}$

Therefore, RUTE's promotion of Telemedicine represents a strengthening of online teaching tools that were applied to a country with local health system disparities and a large territorial extension. Telemedicine, as a medical, health science, and educational methodology can result in shrinking information gaps for healthcare providers and could contribute to the build of a fully connected healthcare global community. ${ }^{19}$

With the support of an easy, free, and public online access resource, the Organizing Committee was able to select and disseminate a vast collection of medical knowledge data and new facts related to the COVID-19 diagnosis and treatment schedules.

The reality of the global health community, triggered by COVID-19, relies on quickly recognizing, selecting, and applying knowledge shared from regions that have figured how to deal with the disease. ${ }^{20}$

The need to adapt to these new challenges required a flexibility that is imperative for this crisis management, as far as upended routines and patterns in the medical practice. ${ }^{21}$ Consequently, the creation of the SIG COVID-19 Brazil RUTE fulfilled its purpose to enhance communication, spread content, and allow distant medical services to connect with each other, in order to exchange prompt medical information, prepare for the growing pandemic and reach a higher standard of health care in many distant hospital services throughout the country. ${ }^{22}$

To promote the use of Telemedicine in the COVID-19 era, various online resources have been developed both from regulatory agencies and private health insurance. ${ }^{23,24}$ Activities involving different specialties, describing views from expertise presented through the platform, helped sharing information throughout the ascending curve of severe cases. A study performed in the Shandong province in China, written by Song et al., ${ }^{25}$ described the importance of the connection between healthcare professionals in the country as well as abroad. The platform was used internally to promote personal protection videos, and it was also used to conduct remote training directed to care for COVID-19 infected patients. A variety of professionals, ranging from experts on intensive care, infectious disease, and respiratory issues were involved. Traditional Chinese medicine practitioners were also invited to connect and divide their experience, raising more than 500,000 individuals in video conferences. $^{25}$

In this present study, more than 50 Brazilian speakers presented multidisciplinary lectures, followed by a debate with a question and answer period in real time, and were joined by 857 attendees in total.

This report is grounded on the first 100 day experience, and our results support that web conferences are a safe, convenient, time-saving, and low-cost solution to rapidly organize a powerful time for healthcare experts. Moreover, 10 international guests from 9 different countries presented their practical professional experiences, during different moments of the pandemic of COVID-19.

This study has limitations. The complete questionnaire rate was low because many participants did not register presence after the session. The system can control only who attended trough the web conference plataform, but not who watched the sessions by streaming. Some participants left the web conference imediately after the lecture and did not wait the questions and answers. Another limitation of the study was the questionnaire formulated in few questions, filled after each session, which may not be enough to check the quality of SIG COVID-19 Brazil RUTE. A new questionnaire more well structured has been created to be applied at the end of the activities, we hope until the end of the year, considering all sessions each participant attended, but without the intention of retention of information about COVID-19.

In parallel to this initiative, a similar project is in progress at a global scale, with the aim of discussing the course of the disease in different countries. Discussion topics include treatment options and obstacles regarding ways to prevent contamination, as well as the need to restructure the health care system. The Panamerican Trauma Society was already organizing weekly video conferences between several countries in the Americas and other continents, but the alarming scenario raised a need for more webinars. The American Association for the Surgery of TraumaInternational Relations Committee (AAST-IrC) and the World Coalition for Trauma Care (WCTC), supported by the University of Miami and Virginia Commonwealth University, have organized a weekly videoconference about COVID-19, covering topics such as 


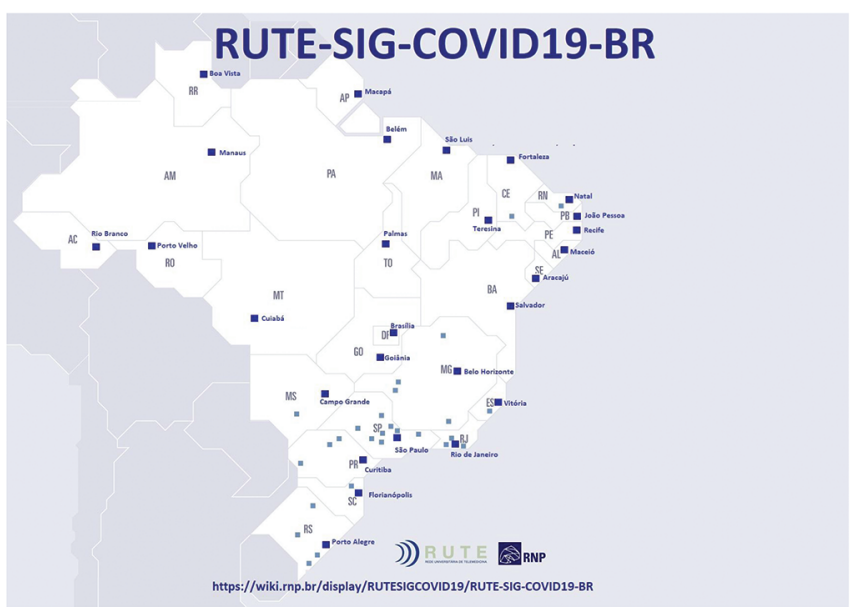

Fig. 3: SIG COVID-19 coverage map, highlighting Brazilian capitals

operational readiness on many instances, varying from hospitals, regional and even national reach. ${ }^{18}$

In conclusion, the experience of working with telemedicine was determinant to create the innovative SIG COVID-19 Brazil RUTE, providing a fast response to professional and student needs of updated knowledge on diagnosis, treatments, and outcomes for the COVID-19 crisis management. In a brief span of time, a month after the first case was published in Brazil, this strategy covered dozens of significant themes, allowing the exchange of transcontinental experiences with participants from all over our country.

\section{ACKNoWledgments}

Thiago Lima Verde (RUTE), Luan Meirelles (RUTE), and Antonio Carlos da Silva II (Unicamp) for their technical support; Isadora MA Fraga (PwC, Toronto, Canada) for English language review; and all guest speakers who participated at SIG COVID-19 Brazil RUTE.

\section{References}

1. Huang C, Wang Y, Li X, et al. Clinical features of patients infected with 2019 novel coronavirus in Wuhan, China. Lancet 2020;395(10223):497506. DOI: 10.1016/S0140-6736(20)30183-5.

2. Jin Y, Yang H, Ji W, et al. Virology, epidemiology, pathogenesis, and control of COVID-19. Viruses 2020;12(4):372. DOI: 10.3390/v12040372.

3. Coronavirus disease 2019 (COVID-19) Situation Report - 51. World Health Organization (WHO). Avaiable at https://www.who.int/docs/ default-source/coronaviruse/situation-reports/20200311-sitrep-51covid-19.pdf?sfvrsn=1ba62e57_10. Accessed on July 1st, 2020.

4. Rodriguez-Morales AJ, Gallego V, Escalera-Antezana JP, et al. COVID-19 in Latin America: the implications of the first confirmed case in Brazil. Travel Med Infect Dis 2020;35:101613. DOI: 10.1016/j. tmaid.2020.101613.

5. WHO Health Emergency Dashboard. WHO (COVID-19). Available at https://covid19.who.int/. Accessed on July 1st, 2020.

6. Nascimento Jr BA, de Melo Rolim LT, Fraga GP, et al. The importance of the epidemic curve for cross-country comparison of COVID-19 mortality: a brief analysis on interpreting the pandemic numbers. Panam J Trauma Crit Care Emerg Surg 2020. DOI: https://www. pajtcces.com//doi/PAJT/pdf/10.5005/jp-journals-10030-1276.

7. Coronavirus Brasil. Available at: https://covid.saude.gov.br/ Accessed on July 1 st, 2020

8. Rede Universitaria de Telemedicina. Available at: https://rute.rnp.br/ Accessed on July 1st, 2020.

9. RUTE-SIG-COVID19-BR. Available at: https://wiki.rnp.br/display/ RUTESIGCOVID19 Accessed on July 1st, 2020.

10. Dorsey ER, Topol EJ. Telemedicine 2020 and the next decade. Lancet 2020;395(10227):859. DOI: 10.1016/S0140-6736(20)30424-4.

11. Eisenstein E, Messina LA. Broadening the frontiers of adolescent health through telemedicine and online networks. Ann Glob Health 2017;83(5-6):713-717. DOI: 10.1016/j.aogh.2017.10.028.

12. Graziano F, Maugeri R, lacopino DG. Telemedicine vs WhatsApp: from tradition to evolution. Neuroreport 2015;26(10):602-603. DOI: 10.1097/WNR.0000000000000393.

13. Giordano V, Koch H, Godoy-Santos A, et al. WhatsApp messenger as an adjunctive tool for telemedicine: an overview. Interact J Med Res 2017;6(2):e11. DOI: 10.2196/ijmr.6214.

14. de Lima Verde Brito TD, Baptista RS, de Lima Lopes PR, et al. The collaborative coordination of special interest groups on the telemedicine university network (RUTE) in Brazil. Stud Health Technol Inform 2015;216:1010. DOI: 10.3233/978-1-61499-564-7-1010.

15. de Lima Verde Brito T, Baptista RS, de Lima Lopes PR, et al. Collaboration between medical professionals: special interest groups in the Brazilian telemedicine university network (RUTE). Telemed J E Health 2019;25(10):902-910. DOI: 10.1089/tmj.2018.0075.

16. Hollander JE, Carr BG. Virtually perfect? Telemedicine for COVID-19. N Engl J Med 2020;382(18):1679-1681. DOI: 10.1056/ NEJMp2003539.

17. Triana AJ, Gusdorf RE, Shah KP, et al. Technology literacy as a barrier to telehealth during COVID-19. Telemed J E Health 2020;26(9):1118-1119. DOI: $10.1089 / \mathrm{tmj} .2020 .0155$.

18. Marttos A. The Panamerican Trauma Society and the global response to COVID-19. Panam J Trauma Crit Care Emerg Surg 2020;9(1):1-2. DOI: 10.5005/jp-journals-10030-1272.

19. Kelly R, Lindgren J, Mack $L$, et al. Avera eCARE: medical student education in telemedicine. Telehealth Med Today 2020;5(2). DOI: 10.30953/tmt.v5.179.

20. Wijesooriya NR, Mishra V, Brand PLP, et al. COVID-19 and telehealth, education, and research adaptations. Paediatr Respir Rev 2020;35:3842. DOI: 10.1016/j.prrv.2020.06.009, ISSN 1526-0542.

21. Loeb AE, Rao SS, Ficke JR, et al. Departmental experience and lessons learned with accelerated introduction of telemedicine during the COVID-19 crisis. J Am Acad Orthop Surg 2020;28(11):e469-e476. DOI: 10.5435/JAAOS-D-20-00380.

22. Katherine $\mathrm{E}$, Chike-Harris, Durham $\mathrm{C}$, et al. Integration of telehealth education into the health care provider curriculum: a review. Telemed J E Health 2020. DOI: 10.1089/tmj.2019.0261.

23. Portnoy J, Waller M, Elliott T. Telemedicine in the era of COVID-19. J Allergy Clin Immunol Pract 2020;8(5):1489-1491. DOI: 10.1016/j. jaip.2020.03.008.

24. Eisenstein E, Kopacek C, Cavalcante SS, et al. Telemedicine: a bridge over knowledge gaps in healthcare. Curr Pediatr Rep 2020. 1-6. DOI: 10.1007/s40124-020-00221-w.

25. Song X, Liu X, Wang C. The role of telemedicine during the COVID-19 epidemic in China-experience from Shandong Province. Crit Care 2020;24(1):178. DOI: 10.1186/s13054-020-02884-9. 